\title{
DETERMINAN KEPUASAN PENGGUNA INSTAGRAM DJPPR TERHADAP INFORMASI SAVINGS BOND RITEL
}

\author{
Maman Suhendra ${ }^{1, *)}$, Dini Privea Prabawati ${ }^{2)}$, Sri Putri Siregar ${ }^{3)}$ \\ 1,*) msuhendra@pknstan.ac.id, Politeknik Keuangan Negara STAN \\ 2) dinipriveap@gmail.com, Direktorat Jenderal Pengelolaan Pembiayaan dan Risiko, Kementerian Keuangan \\ ${ }^{3)}$ putrisiregar171717@gmail.com, Direktorat Jenderal Pengelolaan Pembiayaan dan Risiko, Kementerian Keuangan \\ *email korespondensi
}

\begin{abstract}
The financing contribution from rupiah denominated government bond (SBN) to the State Budget has been increasingly important. This is to ensure the fiscal sustainability for years to come. One source for SBN is SBR as an investing instrument for individual investors. With the relatively high potency in amount and increasingly young investors' animo, then the expansion basis of investors is becoming much more strategic. The strengthening the quality and capacity of online platform like instagram is becoming quite relevant nowadays. This study aims to understand the determinants of DJPPR Instagram users' satisfaction. Utilizing the partial least squares structural equation modeling (PLS-SEM) approach on DeLone \& McLean IS Success Model, it is found that DJPPR Instagram users' satisfaction are affected by the information quality and service quality, not the system quality.
\end{abstract}

Keywords : SBR, information quality, service quality, system, quality

\begin{abstract}
Abstrak
Peran pembiayaan anggaran APBN yang berasal dari SBN berdenominasi rupiah dari waktu ke waktu menjadi semakin penting. Hal ini terutama untuk memastikan kesinambungan fiskal di masa yang akan datang. Salah satu sumber penerimaan pembiayaan bagi SBN adalah SBR sebagai instrumen investasi bagi investor individu. Dengan potensi besaran yang relatif potensial serta animo generasi muda yang semakin meningkat, maka perluasan basis investor pada instrumen ini menjadi semakin strategis. Penguatan kualitas dan kapasitas online platform seperti instagram oleh karenanya menjadi sangat relevan. Penelitian ini bertujuan untuk memahami faktor-faktor yang memengaruhi kepuasan pengguna Instagram DJPPR dalam kerangka perluasan basis investor. Dengan menggunakan pendekatan partial least squares structural equation modeling (PLS-SEM) pada model yang diadaptasi dari DeLone \& McLean IS Success Model, diketahui bahwa kepuasan pengguna Instagram DJPPR dipengaruhi oleh kualitas informasi \& kualitas layanan, bukan oleh kualitas sistem.
\end{abstract}

Kata Kunci: SBR, kualitas informasi, kualitas layanan, kualitas sistem

\section{PENDAHULUAN}

Untuk mengantisipasi kelanjutan risiko ketidakpastian ekonomi akibat Pandemi Covid-19, maka pembiayaan anggaran dalam Anggaran Pendapatan dan Belanja Negara (APBN) Tahun 2021 mencapai Rp 1.006,4 triliun. Pembiayaan ini menurun dari total pembiayaan APBN tahun sebelumnya sebesar Rp 1.039,2 triliun. Porsi terbesar pembiayaan ini diharapkan berasal dari Surat Berharga Negara (SBN) dalam mata uang rupiah (Suryanto, 2020).

Pembiayaan defisit Rp 1.006,4 triliun tersebut dianggarkan dari pembiayaan utang dalam APBN sebesar Rp 1.177,4 triliun. Jumlah ini naik sekitar 34,9\% dari tahun sebelumnya yang sebesar Rp 1.142,5 triliun. Kenaikan pembiayaan utang ini berasal dari penerbitan SBN sebesar Rp 1.207,3 triliun, pembiayaan investasi senilai Rp 184,5 triliun, pembiayaan lainnya sebesar Rp 15,8 triliun, kewajiban pinjaman sebesar $\mathrm{Rp} 2,7$ triliun dan pembiayaan anggaran untuk pemberian pinjaman sekitar Rp 0,4 triliun serta pinjaman yang dicadangkan senilai Rp 29,9 triliun. Melalui strategi ini, pemerintah dapat memperdalam pasar keuangan domestik sehingga diharapkan ikut mendorong pertumbuhan ekonomi (Suryanto, 2020).

Sebagian dari SBN dimaksud adalah SBN ritel (termasuk Savings Bonds Ritel/SBR) untuk investor individu. Penerbitan SBN ritel sepanjang tahun 2020 berhasil memecahkan rekor periode-periode sebelumnya, baik dari sisi nominal penerbitan maupun jumlah investor. Tantangan utama yang dihadapi pada tahun 2020 adalah pembatasan kegiatan marketing SBN 


\section{JURNALKU}

Volume 1 No. 4, Desember 2021

ritel akibat kebijakan pencegahan penularan virus Covid-19. Karenanya strategi marketing harus dilakukan dengan pendekatan berbeda. Kegiatan marketing melalui online platform seperti webinar dan media sosial menjadi andalan utama (Ridwan, 2021).

Total nominal penerbitan SBN ritel tahun 2020 adalah sebesar Rp 76,81 triliun, sementara total investor mencapai jumlah 166.928 investor. Proporsi investor baru adalah sebanyak 43,6 persen atau 72.844 investor. Melanjutkan tren sebelumnya, generasi milenial kembali mendominasi dengan proporsi 39 persen, disusul oleh generasi baby boomers sejumlah 26 persen (Ridwan, 2021).

Salah satu media sosial yang paling sering digunakan oleh anak muda adalah instagram. Instagram menyediakan banyak fitur bukan hanya sarana berbagi informasi foto dan video, tetapi juga dapat menjadi peluang berbisnis. Berdasarkan hasil olah kuesioner 100 responden pengikut akun online shop Instagram @Pluffyschoice, (Willianti \& Oktavianti, 2019) menyampaikan bahwa terdapat pengaruh motif penggunaan media sosial instagram terhadap kepuasan konsumen bersifat sedang dan sebesar $28 \%$. Apabila motif penggunaan media sosial instagram meningkat maka kepuasan konsumen juga akan meningkat.

Sehubungan dengan studi tersebut dan dalam rangka pengembangan strategi perluasan basis investor individu dari kalangan generasi muda, maka penelitian terkait determinan kepuasan pengguna Instagram Direktorat Jenderal Pengelolaan Pembiayaan dan Risiko (DJPPR) Kementerian Keuangan, dengan nama akun @djpprkemenkeu, terkait informasi Saving Bond Ritel (SBR) menjadi relevan. Dengan studi ini diharapkan dapat diketahui faktor-faktor apa saja yang sebenarnya mempengaruhi kepuasan pengguna Instagram DJPPR atas informasi SBR.

Terdapat beberapa studi yang sudah dilaksanakan terkait dengan identifikasi faktorfaktor yang memengaruhi kepuasan pengguna aplikasi online platform, namun yang secara spesifik terkait dengan kepuasan pengguna instagram atas informasi SBR ritel dalam rangka perluasan basis investor saat ini masih sangat terbatas.

\section{KAJIAN PUSTAKA}

Model kesuksesan sistem informasi DeLone dan McLean merupakan model yang relatif sering digunakan untuk mengukur kesuksesan suatu sistem informasi, termasuk aplikasi online platform (Negara \& Pratomo, 2019). Setelah mengkaji ratusan artikel terkait yang dipublikasikan pada jurnal-jurnal sistem informasi yang relevan, maka pada tahun 2003 DeLone dan McLean memperbaiki model kesuksesan sistem informasi dimaksud.

Dalam perbaikan model tersebut, DeLone dan McLean mengganti dimensi kesuksesan menjadi sebagai berikut: Kualitas Sistem (System Quality), Kualitas Informasi (Information Quality), Kualitas Layanan (Service Quality), Kepuasan Pengguna (User Satisfaction), Intensi Memakai (Intention to Use), dan Manfaat bersih (Net Benefits) (DeLone \& McLean, 2003). Gambar 1 berikut merupakan model kesuksesan sistem informasi DeLone \& McLean. 


\section{JURNALKU}

Volume 1 No. 4, Desember 2021

Gambar 1 Model Keberhasilan Sistem Informasi DeLone \& McLean

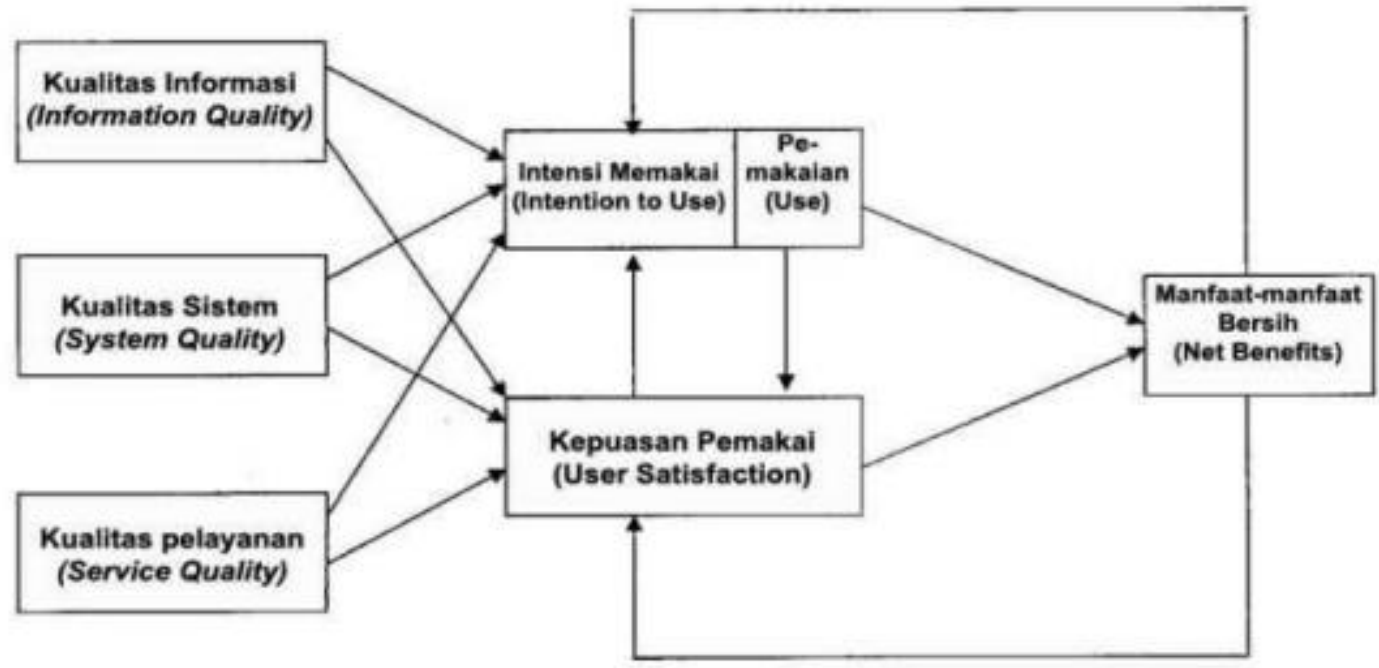

Sumber: Updated D\&M IS Success Model (DeLone \& McLean, 2003)

\section{Kualitas Informasi (Information Quality)}

Dimensi kesuksesan kualitas informasi merupakan karakteristik-karakteristik keluaran yang diinginkan dari suatu sistem informasi. Informasi statistik penjualan terkini atau hargaharga penawaran saat ini merupakan contoh-contoh yang dapat dihasilkan oleh suatu sistem informasi. Dengan demikian dimensi kualitas informasi mengleompokkan ukuran-ukuran terkait mutu informasi yang dihasilkan oleh sistem informasi dan kegunaaannnya. Dimensi kualitas informasi sering dilihat sebagai pendahulu kunci dari dimensi kepuasan pengguna (Dwivedi et al., 2012).

Beberapa indikator terkait dengan pengukuran dimensi kualitas informasi ini adalah accuracy, adequacy, availability, completeness, conciseness, consistency, format, precision, relevance, reliability, scope, timeliness, understandability, uniqueness, usability, dan usefulness (Dwivedi et al., 2012).

Berdasarkan analisis data pada industri otomotif XPPS dengan menggunakan teknik structural equation modeling (SEM) terkonfirmasi bahwa kualitas informasi berpengaruh positif terhadap kepuasan pengguna (Roky \& Meriouh, 2015). Lebih lanjut, disampaikan pula bahwa kualitas informasi memengaruhi secara positif dan signifikan kepuasan pengguna atas layanan sistem informasi her registrasi iGracias Universitas Telkom (Negara \& Pratomo, 2019).

Selanjutnya dengan mengadopsi sistem, layanan dan kualitas informasi dalam Model Keberhasilan Sistem Informasi DeLone \& Mclean sebagai variabel eksternal dan mengintegrasikan 3 (tiga) dimensi persepsi kemanfaatan (perceived usefulness), persepsi kemudahan penggunaan (perceived ease of use), dan keinginan untuk menggunakan (intention to use) yang mengacu pada Venkatesh and Davis' updated Technology Acceptance Model (TAM), ditemukan bahwa pengaruh kualitas informasi berpengaruh positif terhadap kepuasan pengguna (Pai \& Huang, 2011).

Berdasarkan model penelitian terkait di atas dan beberapa temuan dalam studi terkait maka dirumuskan hipotesis sebagai berikut:

$\mathrm{H}_{1}$ : Kualitas Informasi terkait SBR memiliki hubungan yang positif dengan kepuasan pengguna Instagram DJPPR.

\section{Kualitas Layanan (Service Quality)}

Dimensi kesuksesan dari kualitas layanan mencerminkan mutu dari dukungan bagian sistem informasi dan personil teknologi informasi kepada pengguna, seperti pelatihan, penyediaan nomor aduan (hotline), atau penyediaan pusat aduan (helpdesk). Dimensi ini 


\section{JURNALKU}

Volume 1 No. 4, Desember 2021

merupakan perbaikan dari DeLone \& McLean Information System (IS) Success Model (Dwivedi et al., 2012). Adapun ukuran-ukuran terkait dengan konstruk kualitas layanan ini adalah assurance, empathy, flexibility, interpersonal quality, intrinsic quality, IS training, reliability, responsiveness, dan tangibles (Dwivedi et al., 2012).

Berdasarkan studi terkait dengan kepuasan intruktur dalam menggunakan Learning Management System (LMS), terkonfirmasi antara lain bahwa kualitas layanan berpengaruh positif terhadap kepuasan pengguna (Almarashdeh, 2016). Dan terkait juga dengan penelitian kepuasan pengguna e-learning system di Iran di atas ditemukan juga bahwa kualitas layanan berpengaruh positif terhadap kepuasan pengguna (Hassanzadeh et al., 2012). Terkonfirmasi pula bahwa kualitas layanan memengaruhi secara positif dan signifikan kepuasan pengguna atas layanan sistem informasi her registrasi iGracias Universitas Telkom (Negara \& Pratomo, 2019).

Namun berdasarkan analisis data pada industri otomotif XPPS sebelumnya terkonfirmasi bahwa kualitas layanan tidak berpengaruh terhadap kepuasan pengguna (Roky \& Meriouh, 2015). Hal ini sejalan dalam konteks studi kajian kepuasan pengguna sistem informasi pada beberapa kantor pemerintah di Indonesia dimana ditemukan bahwa kualitas layanan tidak berpengaruh signifikan terhadap kepuasan pengguna (Mardiana et al., 2015).

Sehubungan dengan model penelitian terkait di atas dan beberapa temuan dalam studi diatas maka dirumuskan hipotesis sebagai berikut:

$\mathrm{H}_{2}$ : Kualitas Layanan terkait SBR memiliki hubungan yang positif dengan kepuasan pengguna Instagram DJPPR.

\section{Kualitas Sistem (System Quality)}

Dimensi kesuksesan dari konstruk kualitas sistem merupakan karakteristikkarakteristik yang diinginkan dari suatu sistem informasi. Karena hal ini, konstruk kualitas sistem mengelompokkan ukuran-ukuran dari sistem informasi itu sendiri. Ukuran-ukuran ini secara khusus menitikberatkan pada aspek-aspek kegunaan dan karakteristik-karakteristik kinerja dari sistem terkait (Dwivedi et al., 2012).

Terdapat beberapa ukuran terkait dengan konstruk kualitas sistem ini, anatara lain: access, convenience, customization, data accuracy, data currency, ease of learning, ease of use, efficiency, flexibility, integration, interactivity, navigation, reliability, response time, sophistication, system accuracy, system features, dan turnaround time (Dwivedi et al., 2012).

Menggunakan hasil olah data tanggapan 186 siswa pengguna e-Portfolio dari berbagai institusi pendidikan tinggi, didapatkan kesimpulan bahwa kualitas sistem berpengaruh signifikan dan positif terhadap kepuasan pengguna sistem informasi (Balaban et al., 2013). Sementara itu, untuk memastikan bahwa e-learning direncanakan dengan tepat dan memberikan manfaat sebagaimana yang diharapkan, sebuah riset komprehensif yang melibatkan beberapa perguruan tinggi di Iran, sebagian disimpulkan bahwa bahwa kualitas sistem berpengaruh positif terhadap kepuasan pengguna e-learning system (Hassanzadeh et al., 2012).

Selanjutnya disampaikan pula bahwa kualitas sistem memengaruhi secara positif dan signifikan kepuasan pengguna atas layanan sistem informasi her registrasi iGracias Universitas Telkom (Negara \& Pratomo, 2019). Namun berdasarkan analisis data pada industri otomotif XPPS juga terkonfirmasi bahwa kualitas sistem tidak berpengaruh terhadap kepuasan pengguna (Roky \& Meriouh, 2015).

Berdasarkan model penelitian terkait diatas dan beberapa temuan dalam studi terdahulu maka dirumuskan hipotesis sebagai berikut:

$\mathrm{H}_{3}$ : Kualitas Sistem terkait SBR memiliki hubungan yang positif dengan kepuasan pengguna Instagram DJPPR. 


\section{JURNALKU}

Volume 1 No. 4, Desember 2021

\section{Kepuasan Pengguna (User Satisfaction)}

Dimensi kesuksesan dari konstruk kepuasan pengguna terkait dengan tingkat kepuasan pengguna dalam memanfaatkan sebuah sistem informasi. Konstruk ini merupakan salah satu ukuran paling penting dalam kesuksesan sebuah sistem informasi. Adapun ukuran-ukuran terkait dengan konstruk ini antara lain: adequacy, effectiveness, efficiency, enjoyment, infomation satisfaction, overall satisfaction, dan system satisfaction (Dwivedi et al., 2012).

Studi atas faktor-faktor yang memengaruhi kepuasan pengguna atas layanan sistem informasi her registrasi iGracias Universitas Telkom juga mengkonfirmasi bahwa secara simultan kualitas informasi, layanan, dan sistem berpengaruh signifikan terhadap kepuasan pengguna (Negara \& Pratomo, 2019).

\section{METODE}

Data pendahuluan penelitian diperoleh melalui pelaksanaan studi literatur. Berdasarkan hasil studi literatur, lalu dikembangkan kuisioner penelitian sebagai instrumen survei dengan isian skala Likert 6 pilihan. Adapun pertanyaan-pertanyaan dalam survei dapat dilihat pada Tabel 1 di berikut ini.

Tabel 1 Daftar Pertanyaan Kuisioner

\begin{tabular}{|c|c|c|}
\hline \multicolumn{3}{|c|}{ Information Quality (IFQ) } \\
\hline IFQ1 & Informasi SBR dalam Instagram DJPPR sangat mudah dipahami & Understandability \\
\hline IFQ2 & Informasi SBR sangat lengkap di Instagram DJPPR & Completeness \\
\hline IFQ3 & Informasi SBR di Instagram DJPPR sangat akurat & Accuracy \\
\hline IFQ4 & Informasi SBR di Instagram DJPPR selalu up-to-date & Timeliness \\
\hline IFQ5 & Informasi SBR di Instagram DJPPR sesuai dengan kebutuhan saya & Relevance \\
\hline \multicolumn{3}{|c|}{ System Quality (SYQ) } \\
\hline SYQ1 & $\begin{array}{l}\text { Platform Instagram DJPPR (yang memberikan edukasi tentang } \\
\text { SBR) mudah diakses }\end{array}$ & Access \\
\hline SYQ2 & $\begin{array}{l}\text { Platform Instagram DJPPR (yang memberikan edukasi tentang } \\
\text { SBR) mudah digunakan }\end{array}$ & $\begin{array}{l}\text { Ease of Use \& } \\
\text { Efficiency }\end{array}$ \\
\hline SYQ3 & $\begin{array}{l}\text { Platform Instagram DJPPR (yang memberikan edukasi tentang } \\
\text { SBR) dapat diakses kapan saja }\end{array}$ & Flexibility \\
\hline SYQ4 & $\begin{array}{l}\text { Platform Instagram DJPPR (yang memberikan edukasi tentang } \\
\text { SBR) memiliki fitur tambahan seperti reels dan stories yang } \\
\text { menarik dan menyenangkan untuk dilihat }\end{array}$ & Convenience \\
\hline SYQ5 & $\begin{array}{l}\text { Seluruh fitur Instagram DJPPR (yang menyediakan informasi } \\
\text { SBR) dapat diandalkan }\end{array}$ & Reliability \\
\hline SYQ6 & $\begin{array}{l}\text { Platform Instagram DJPPR (yang memberikan edukasi tentang } \\
\text { SBR) membuka kesempatan follower untuk berinteraksi dua arah } \\
\text { (Cth: 1) Interaksi di kolom komentar atau interaksi saat sesi Q\&A } \\
\text { di IG TV; 2) Interaksi terhadap terhadap IG Stories; Interaksi saat } \\
\text { IG Live bersama narasumber; atau 4) Interaksi melalui Direct } \\
\text { Message) }\end{array}$ & Interactivity \\
\hline \multicolumn{3}{|c|}{ Service Quality (SVQ) } \\
\hline SVQ1 & $\begin{array}{l}\text { Admin Instagram DJPPR memberikan informasi SBR secara } \\
\text { meyakinkan dan dapat diandalkan }\end{array}$ & $\begin{array}{l}\text { Reliability \& } \\
\text { Assurance }\end{array}$ \\
\hline SVQ2 & $\begin{array}{l}\text { Admin Instagram DJPPR responsif memberikan pelayanan } \\
\text { informasi SBR }\end{array}$ & Responsiveness \\
\hline SVQ3 & $\begin{array}{l}\text { Admin instagram ramah dalam memberikan pelayanan informasi } \\
\text { SBR }\end{array}$ & $\begin{array}{l}\text { Interpersonal } \\
\text { Quality }\end{array}$ \\
\hline SVQ4 & $\begin{array}{l}\text { Admin Instagram selalu menjawab pertanyaan terkait SBR } \\
\text { (misalnya di kolom komentar pada foto di-feed, IGTV, IG Live, } \\
\text { atau Q\&A di stories) }\end{array}$ & Empathy \\
\hline
\end{tabular}




\begin{tabular}{|c|c|c|}
\hline URS1 & $\begin{array}{l}\text { Secara keseluruhan, saya puas dengan informasi SBR di Instagram } \\
\text { DJPPR }\end{array}$ & $\begin{array}{l}\text { Overall } \\
\text { Satisfaction \& } \\
\text { Information } \\
\text { Satisfaction }\end{array}$ \\
\hline URS2 & $\begin{array}{l}\text { Saya puas dengan kecukupan informasi SBR yang disampaikan } \\
\text { melalui Instagram DJPPR }\end{array}$ & Adequacy \\
\hline URS3 & $\begin{array}{l}\text { Saya puas karena Instagram DJPPR berhasil membuat saya } \\
\text { memahami SBR lebih cepat dan mudah }\end{array}$ & $\begin{array}{l}\text { Effectiveness } \\
\text { (mudah) \& } \\
\text { Efficiency (cepat) }\end{array}$ \\
\hline
\end{tabular}

Sumber: hasil olahan tim peneliti

Survei melalui penyebaran kuesioner dipilih mengingat beberapa keuntungan yang sesuai dengan tujuan penelitian (Fattah \& Setyadi, 2021). Studi ini menggunakan teknik multistage purposive random samping. Pada tahap pengumpulan data kuantitatif hasil survei, kuesioner dalam format Google Form dikirimkan secara acak melalui email dan online platform (seperti grup Whatsapp) yang relevan.

Sebanyak 107 orang responden mengisi kusioner, dan setelah melalui proses seleksi dan kelayakan dipilih 100 dari 107 kuisioner yang telah diisi untuk diolah lebih lanjut (93,46\% dari keseluruhan kuisioner yang masuk). Data dianalisis dengan pendekatan partial least squares structural equation modeling (PLS-SEM) dengan aplikasi Smart PLS 3.0.

Hasil olah data dimaksud selanjutnya dianalisis untuk memenuhi kriteria kelayakan data berdasarkan nilai-nilai: Cronbach's Alpha $(0,6)$, Composite Reliability $(0,7)$, AVE $(0,5)$ dan Loading Factor $(0,7)$. T-Statistic yang digunakan adalah diatas 1,96 pada tingkat keyakinan (confident interval) sebesar 95\% (Fattah \& Setyadi, 2021). Pengujian validitas dan realibilitas data dapat dilihat pada Tabel 2. Adapun hasil pengujian hipotesis model penelitian dapat dilihat pada Tabel 3 .

Model yang digunakan dalam studi ini dapat dilihat pada Gambar 2. Model tersebut diadaptasi dari model yang dipakai dalam studi Pengaruh Kualitas Sistem, Kualitas Informasi dan Kualitas Layanan Her Registrasi iGracias terhadap Kepuasan Pengguna (Negara \& Pratomo, 2019). Studi ini mengidentifikasi bagaimana pengaruh faktor-faktor kepuasan pengguna aplikasi sistem informasi iGracias yang digunakan di salah satu universitas di Kota Bandung. 
Gambar 2 Struktur Model

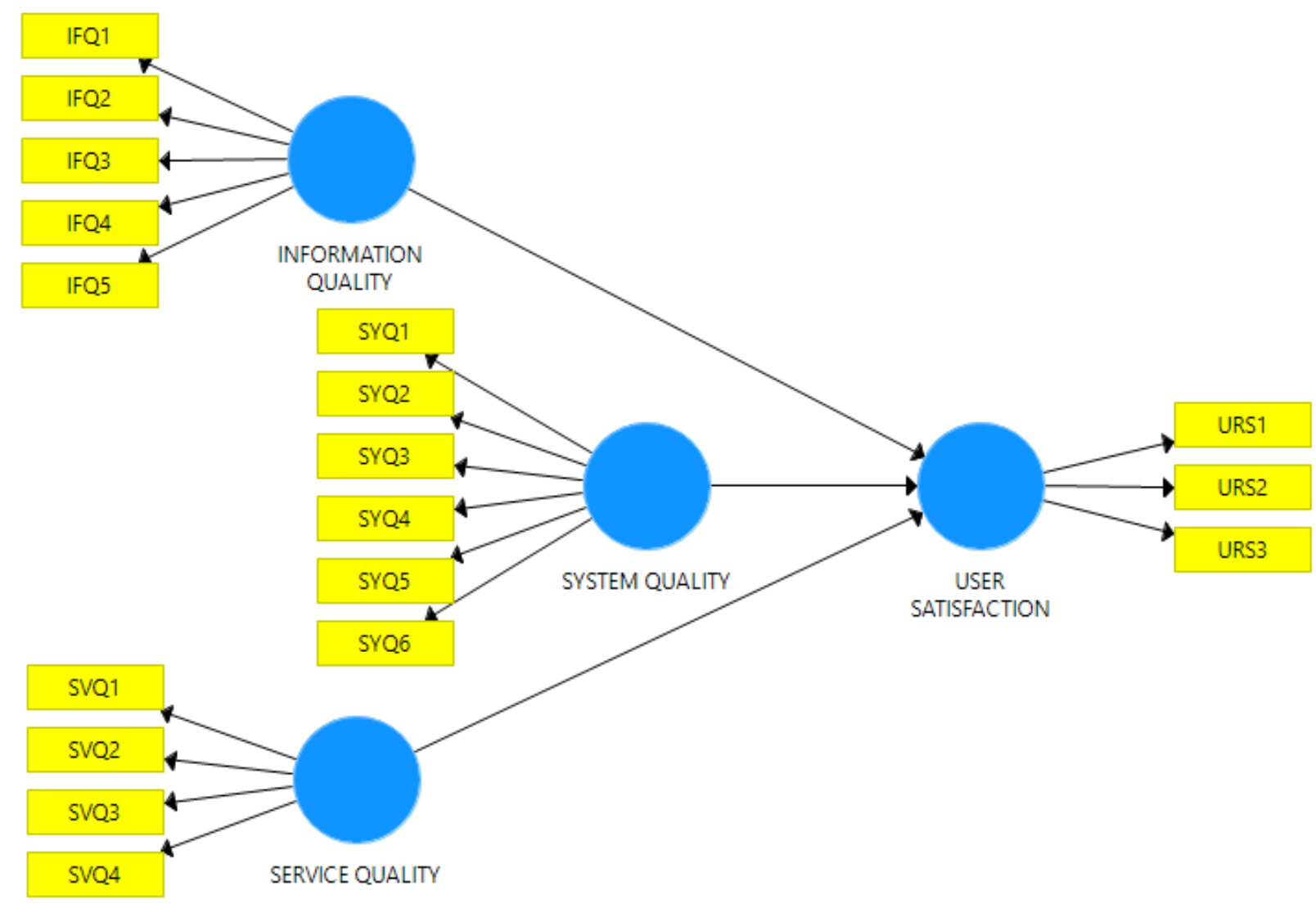

Sumber: Output Smart PLS 3.0

Keterangan:

IFQ : Information Quality

SYQ : System Quality

SVQ : Service Quality

URS : User Satisfaction

\section{HASIL DAN PEMBAHASAN}

Dengan pendekatan partial least squares structural equation modeling (PLS-SEM) melalui penggunaan aplikasi Smart PLS 3.0, selanjutnya dilakukan uji validasi dan realibilitas data untuk mengetahui apakah data lapangan yang berasal dari pengisian kusioner sebelumnya telah sesuai dengan model yang bersangkutan. Kualitas pengukuran model ini ditentukan dengan validitas dan realibilitas data dimaksud. Setelah pengukuran validitas dan realibilitas, lalu dilakukan uji hipotesis.

Tabel 2 Pengujian Validitas dan Realibilitas

\begin{tabular}{cccccc}
\hline Konstruk & Indikator & $\begin{array}{c}\text { Cronbach's } \\
\text { Alpha Value }\end{array}$ & $\begin{array}{c}\text { Composite } \\
\text { Reliability }\end{array}$ & $\begin{array}{c}\text { Average } \\
\text { Variance } \\
\text { Extracted (AVE) }\end{array}$ & $\begin{array}{c}\text { Outer } \\
\text { Loadings }\end{array}$ \\
\hline \multirow{2}{*}{ IFQ } & IFQ1 & 0.890 & 0.919 & 0.694 & 0.824 \\
& IFQ2 & & & & 0.844 \\
& IFQ3 & & & & 0.853 \\
& IFQ4 & & & & 0.833 \\
& IFQ5 & & & & 0.810 \\
\hline SVQ & SVQ1 & 0.920 & 0.944 & & 0.907 \\
& SVQ2 & & & & 0.922
\end{tabular}




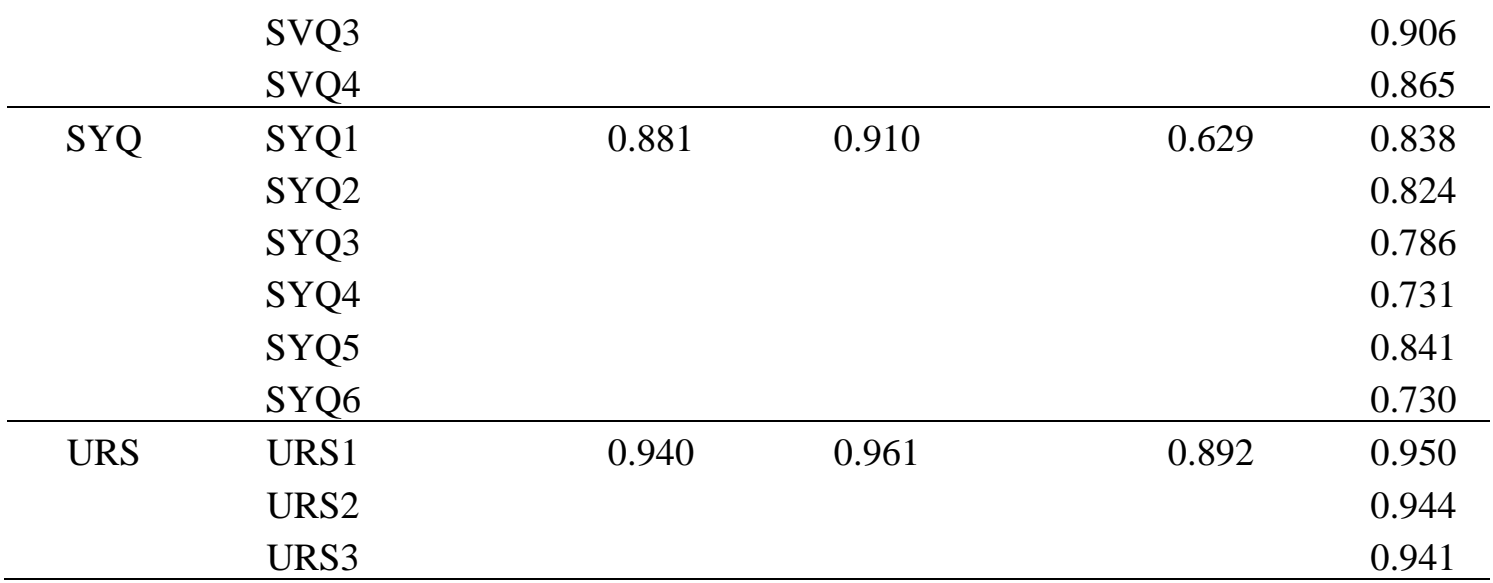

Sumber: Output Smart PLS 3.0

Berdasarkan hasil pengujian validitas dan realibilitas pada Tabel 1, dapat dilihat bahwa baik variabel maupun indikator yang digunakan adalah valid dan reliabel. Keseluruhan perhitungan Outer Loadings berada pada angka sekitar 0,6-0,7 (pembulatan) yang berarti bahwa semua indikator yang digunakan valid. Selanjutnya dapat dilihat bahwa nilai Cronbach's Alpha, Composite Reliability, dan Average Variance Extracted ( $A V E$ ) berada diatas 0,5. Hal ini menunjukkan bahwa variabel yang dinilai konsisten karena akan memberikan hasil yang relatif sama bila dilakukan proses running model yang berulang.

Tabel 3 Pengujian Hipotesis

\begin{tabular}{lcccc}
\hline \multicolumn{1}{c}{ Jalur } & Hipotesis & $\begin{array}{c}\text { T- } \\
\text { Statistic }\end{array}$ & $\begin{array}{c}\text { P- } \\
\text { Values }\end{array}$ & Keputusan \\
\hline $\begin{array}{l}\text { INFORMATION } \\
\text { QUALITY -> USER }\end{array}$ & $\mathrm{H}_{1}$ & 3.280 & 0.001 & $\mathrm{H}_{1}$ diterima \\
SATISFACTION & & & & \\
\hline $\begin{array}{l}\text { SERVICE QUALITY -> } \\
\text { USER SATISFACTION }\end{array}$ & $\mathrm{H}_{2}$ & 3.256 & 0.001 & $\mathrm{H}_{2}$ diterima \\
\hline $\begin{array}{l}\text { SYSTEM QUALITY -> } \\
\text { USER SATISFACTION }\end{array}$ & $\mathrm{H}_{3}$ & 0.971 & 0.332 & $\mathbf{H}_{3}$ ditolak \\
\hline
\end{tabular}

Sumber: Output Smart PLS 3.0

Merujuk pada Tabel 2, hasil pengujian hipotesis menyatakan bahwa $\mathrm{H}_{1}$ : Kualitas Informasi terkait SBR memiliki hubungan yang positif dengan kepuasan pengguna Instagram DJPPR, diterima dengan kepuasan pengguna signifikan dipengaruhi Kualitas Informasi (PValue $=0.001<0.05 \&$ T-Statistic $=3,280>1,96)$. Selanjutnya $\mathrm{H}_{2}$ : Kualitas Pelayanan terkait SBR memiliki hubungan yang positif dengan kepuasan pengguna Instagram DJPPR, juga diterima dengan Kepuasan Pengguna signifikan dipengaruhi Kualitas Pelayanan (PValue $=0.001<0.05$ atau T-Statistic $=3,256>1,96$ ). Namun $\mathrm{H}_{3}$ : Kualitas Sistem terkait SBR memiliki hubungan yang positif dengan kepuasan pengguna Instagram DJPPR, ditolak karena Kepuasan Pengguna tidak signifikan dipengaruhi Kualitas Sistem (P-Value $=0.332>0.05$ atau T-Statistic $=0,971<1,96)$.

\section{PENUTUP}

\section{Simpulan}

Dalam konteks penyebaran informasi/edukasi terkait SBR, kepuasan pengguna Instagram DJPPR dipengaruhi oleh kualitas informasi \& kualitas layanan sebagai penerjemahan atas kualitas informasi, interaksi dan aspirasi antara penyedia dan pengguna informasi. Namun demikian, kualitas sistem tidak menunjukkan pengaruh terhadap kepuasan pengguna instagram atas informasi SBR.

Temuan di atas merupakan masukan berharga dalam pengembangan strategi perluasan 


\section{JURNALKU}

Volume 1 No. 4, Desember 2021

basis investor SBR utamanya kalangan generasi muda. Berdasarkan diskusi tim peneliti yang sebagian bekerja di DJPPR, paling tidak paling tidak ada 2 (dua) strategi yang bisa dipertimbangkan dalam jangka pendek yakni: (1) elaborasi action planning terkait strategi komunikasi aktif DJPPR dan (2) Penguatan platform Instagram DJPPR untuk mendukung inisiatif strategis DJPPR dalam upaya perluasan basis investor.

\section{Saran}

Kedepan, untuk penguatan strategi perluasan basis investor secara lebih baik lagi, maka penelitian kedepan disarankan untuk: (a) lebih memperkaya keberagaman responden pada tingkat variasi usia dan pekerjaan; (b) meneliti dan mengukur intention to use and use dan net benefits sesuai dengan model lengkap Delone \& McLean IS Success Model; (c) mendalami penyebab kualitas sistem tidak berpengaruh terhadap kepuasan pengguna Instagram DJPPR; (d) dilakukan secara lebih komprehensif dengan menerapkan hybrid theory (integrated theory) yakni menggabungkan teori-teori dan referensi literatur yang relevan (seperti investor behavior, information system dan satisfaction) untuk bisa meneliti variabelvariabel yang lebih luas tentang kepuasan pengguna media sosial DJPPR; dan (e) meneliti media-media sosial lain yang turut bisa dipergunakan dalam mendukung edukasi SBR (seperti tiktok, dan lain-lain).

\section{DAFTAR PUSTAKA}

Almarashdeh, I. (2016). Sharing instructors experience of learning management system: A technology perspective of user satisfaction in distance learning course. Computers in Human Behavior, 63, 249-255. https://doi.org/10.1016/j.chb.2016.05.013

Balaban, I., Mu, E., \& Divjak, B. (2013). Development of an electronic Portfolio system success model: An information systems approach. Computers and Education, 60(1), 396-411. https://doi.org/10.1016/j.compedu.2012.06.013

DeLone, W. H., \& McLean, E. R. (2003). The DeLone and McLean model of information systems success: A ten-year update. Journal of Management Information Systems, 19(4), 9-30. https://doi.org/10.1080/07421222.2003.11045748

Dwivedi, Y. K., Wade, M. R., \& Schneberger, S. L. (2012). [Intergrated Series in Information Systems] Informations Systems Theory: Vol.28 ||The Updated DeLone and McLean Model of Information Systems Success. In Springer (Vol. 28, Issue May, p. 461). https://doi.org/10.1007/978-1-4419-6108-2_1

Fattah, A., \& Setyadi, R. (2021). Determinants Effectiveness Information Technology Governance in Higher Education Institution ( HEI ) using partial least squares structural equation modeling approach ( PLS-SEM) structural equation modeling approach ( PLSSEM ). Journal of Physics: Conference Series. https://doi.org/10.1088/17426596/1807/1/012007

Hassanzadeh, A., Kanaani, F., \& Elahi, S. (2012). A model for measuring e-learning systems success in universities. Expert Systems with Applications, 39(12), 10959-10966. https://doi.org/10.1016/j.eswa.2012.03.028

Mardiana, S., Tjakraatmadja, J. H., \& Aprianingsih, A. (2015). Validating the Conceptual Model for Predicting Intention to Use as Part of Information System Success Model: The Case of an Indonesian Government Agency. Procedia Computer Science, 72, 353360. https://doi.org/10.1016/j.procs.2015.12.150

Negara, V. P., \& Pratomo, D. (2019). Pengaruh Kualitas Sistem, Kualitas Informasi Dan Kualitas Layanan Her Registrasi iGracias Terhadap Kepuasan Pengguna. JAF- Journal of Accounting and Finance, 1(01), 33. https://doi.org/10.25124/jaf.v1i01.903

Pai, F. Y., \& Huang, K. I. (2011). Applying the Technology Acceptance Model to the introduction of healthcare information systems. Technological Forecasting and Social 


\section{JURNALKU}

Volume 1 No. 4, Desember 2021

Change, 78(4), 650-660. https://doi.org/10.1016/j.techfore.2010.11.007

Ridwan, D. (2021). SBN Ritel Memikat Investor Muda untuk Bantu Pemulihan Ekonomi

Terdampak COVID-19. Kumparan.Com. https://kumparan.com/deni-ridwan/sbn-ritelmemikat-investor-muda-untuk-bantu-pemulihan-ekonomi-terdampak-covid-19$1 \mathrm{v} 8 \mathrm{PHd} 69 \mathrm{NdC}$

Roky, H., \& Meriouh, Y. Al. (2015). Evaluation by Users of an Industrial Information System (XPPS) Based on the DeLone and McLean Model for IS Success. Procedia Economics and Finance, 26(0), 903-913. https://doi.org/10.1016/s2212-5671(15)00903$\mathrm{X}$

Suryanto, V. (2020). Pembiayaan APBN 2021 Rp 1.006,4 triliun, pemerintah berupaya jaga rasio utang. Kontan.Co.Id. https://nasional.kontan.co.id/news/pembiayaan-apbn-2021rp-10064-triliun-pemerintah-berupaya-jaga-rasio-utang

Willianti, C., \& Oktavianti, R. (2019). Pengaruh Motif Penggunaan Media Sosial Instagram terhadap Kepuasan Konsumen (Studi pada Followers @ pluffyschoice). Prologia, 3(1), 47. https://doi.org/10.24912/pr.v3i1.6205 